\title{
STUDIES ON PHENOLIC STEROIDS IN HUMAN SUBJECTS. II. THE METABOLIC FATE AND HEPATO-BILIARY- ENTERIC CIRCULATION OF C14-ESTRONE AND C14-ESTRADIOL IN WOMEN ${ }^{1}$
}

\author{
BY AVERY A. SANDBERG AND W. ROY SLAUNWHITE, JR. \\ (From the Departments of Medicine and Biochemistry, Roswell Park Memorial Institute, \\ Buffalo, N. Y.)
}

(Submitted March 13, 1957 ; accepted April 25, 1957)

It has been known for a number of years that only a small percentage of the metabolites of administered estrone or estradiol can be definitely identified in the urine of human subjects $(1-6)$. At the most, 10 to 20 per cent of the injected estrogen were recovered in the urine either by chemical or biological assays. The presence of estrogens in bile of animals and in the feces of women had been known since $1928(7,8)$, but it was not until the efforts of Cantarow, Pearlman, Paschkis, Rakoff, Hansen and Walking that biliary excretion in the dog was shown to constitute a major route of excretion of estrogens (9-13). Subsequently, these investigators demonstrated substantial estrogenic activity in the bile of pregnant women (14). Interestingly, it was shown that the estrogens in the bile of animals existed in the free form, in contrast to the presence of conjugated steroids in the bile of pregnant women $(6,13)$. Based on their extensive experiments, these authors advanced the theory that estrogens participate in an enterohepatic circulation.

Significant biliary excretion of estrone labelled with radioactive bromine and estradiol labelled with $\mathrm{I}^{131}$ was demonstrated when these isotopes became available $(15,16)$. Unfortunately, the inclusion of the halogens renders the estrogens biologically inactive and makes the results of the studies difficult to compare with those obtained using endogenous steroids. Furthermore, precise quantification of biliary and urinary estrogen excretion was not possible due to lack of knowledge of all of the estrogen metabolites and imperfections of the methods used for their determination.

The availability of $\mathrm{C}^{14}$-labelled estrone and estradiol has made it possible to study the metabolic

1 This study was suported in part by a grant (A-1240) from the National Institute of Arthritis and Metabolic Diseases, National Institutes of Health, U. S. Public Health Service. fate of these steroids more accurately. Such studies have been performed by Beer and Gallagher $(17,18)$ in human subjects. They demonstrated that about 65 per cent of the radioactivity of $\mathrm{C}^{14}$ estrone or $\mathrm{C}^{14}$-estradiol were excreted in the urine when these steroids were injected either intramuscularly or intravenously. The authors interpreted their experiments to mean that biliary and intestinal elimination played a minor role in the metabolism of estrogens in human subjects. It should be pointed out that while Beer and Gallagher $(17,18)$ determined the radioactivity in the feces of some of their subjects, no studies on biliary excretion were performed. No reports have appeared on the clearance of $\mathrm{C}^{14}$-estrogens from the blood, although two reports have indicated rapid clearance of injected large amounts of estrogens $(5,19)$.

Even though the circulating estrogens have not been definitely identified in human subjects, some evidence has been presented to show that considerable estrogenic activity may be associated with the erythrocytes of blood (20-22) and may exceed the levels present in plasma $(20,21)$.

In this paper we wish to present data on the distribution of radioactivity in the bile, feces and urine following the intravenous injection of $\mathrm{C}^{14}$ estrone or $\mathrm{C}^{14}$-estradiol in women. The rate of clearance from the blood of the free steroids and their conjugated metabolites will be presented. In addition, the distribution of radioactivity in erythrocytes will be reported. The isolation and identification of the various metabolites are the subjects of separate communications (23).

\section{METHODS AND MATERIALS}

One to two $\mu \mathrm{c}$. of $16-\mathrm{C}^{16}$-estrone $\left(E_{1}\right)$ or $16-C^{14}$-estra$\operatorname{diol}-17 \beta\left(E_{2}\right)^{2}$ (both $1 \mu \mathrm{c}$. per $370 \mu \mathrm{g}$.) were injected

\footnotetext{
$2 \mathrm{C}^{16}$-estrone and $\mathrm{C}^{16}$-estradiol were purchased from Charles E. Frosst \& Co., Montreal, Canada. When the preparations were chromatographed in our laboratory,
} 
TABLE I

Clinical data pertaining to experimental subjects

\begin{tabular}{|c|c|c|c|c|c|}
\hline Subject & Age & Wt. & Steroid & $\begin{array}{l}\text { Relation to } \\
\text { menstrual cycle }\end{array}$ & Diagnosis \\
\hline $\begin{array}{l}\text { M.Su. } \\
\text { V.S. } \\
\text { P. G. } \\
\text { P. Go. } \\
\text { R. C. } \\
\text { A. D. } \\
\text { M.S. }\end{array}$ & $\begin{array}{l}27 \\
21 \\
32 \\
20 \\
23 \\
24 \\
66\end{array}$ & $\begin{array}{l}\text { K8. } \\
63.0 \\
53.0 \\
53.0 \\
50.0 \\
47.7 \\
60.0 \\
44.5\end{array}$ & $\begin{array}{l}E_{1} \\
E_{1} \\
E_{1} \\
E_{1} \\
E_{1} \\
E_{2} \\
E_{1}+\end{array}$ & $\begin{array}{l}2 \text { days pre-period } \\
\text { Middle } \\
\text { Middle } \\
7 \text { days post-period } \\
\text { Middle } \\
4 \text { days post-period } \\
\text { Post-menopause }\end{array}$ & $\begin{array}{l}\text { Normal } \\
\text { Normal } \\
\text { Normal } \\
\text { Normal } \\
\text { Normal } \\
\text { Normal } \\
\text { Sarcoma of leg (pre-op.) }\end{array}$ \\
\hline $\begin{array}{l}\text { M.P. } \\
\text { E. K. }\end{array}$ & $\begin{array}{l}44 \\
52\end{array}$ & $\begin{array}{l}50.9 \\
43.3\end{array}$ & $\mathrm{E}_{1}+$ & $\begin{array}{l}1 \text { day post-period } \\
\text { Post-menopause }\end{array}$ & $\begin{array}{l}\text { Carcinoma of breast (post-op.) } \\
\text { Carcinoma of tongue with metastases }\end{array}$ \\
\hline $\begin{array}{l}\text { C. M. } \\
\text { D.F. } \\
\text { J. B. }\end{array}$ & $\begin{array}{l}56 \\
29 \\
32\end{array}$ & $\begin{array}{r}103.9 \\
60.9 \\
64.0\end{array}$ & $\underset{\mathrm{E}_{2}}{\mathrm{E}_{2}}$ & $\begin{array}{l}\text { Post-menopause } \\
7 \text { days pre-period } \\
\text { Period began } 1 \text { day } \\
\text { after injection }\end{array}$ & $\begin{array}{l}\text { Carcinoma of breast, chronic pyelonephritis } \\
\text { Carcinoma of breast (pre-op.) } \\
\text { Carcinoma of breast (pre-op.) }\end{array}$ \\
\hline $\begin{array}{l}\text { G. D. } \\
\text { M. B. } \\
\text { M. K. }\end{array}$ & $\begin{array}{l}58 \\
39 \\
51\end{array}$ & $\begin{array}{l}69.0 \\
46.8 \\
49.1\end{array}$ & $\frac{E_{2}}{E_{2}}$ & $\begin{array}{l}\text { Post-menopause } \\
7 \text { days post-period } \\
7 \text { days post-period }\end{array}$ & $\begin{array}{l}\text { Leiomyosarcoma, diabetes mellitus } \\
\text { Carcinoma of breast (post-op.) } \\
\text { Carcinoma of breast (post-op.) }\end{array}$ \\
\hline $\begin{array}{l}\text { B. A. } \\
\text { S. R. } \\
\text { F. M. }\end{array}$ & $\begin{array}{l}30 \\
25 \\
39\end{array}$ & $\begin{array}{l}99.4 \\
65.9 \\
68.2\end{array}$ & $\begin{array}{l}\mathbf{E}_{1} \\
\mathbf{E}_{2} \\
\mathbf{E}_{1}\end{array}$ & $\begin{array}{l}\text { Pregnant } \\
\text { Pregnant } \\
1 \text { day pre-period }\end{array}$ & $\begin{array}{l}\text { Para IV, pregnancy in 8th month } \\
\text { Para III, pregnancy in 9th month } \\
\text { T-tube drainage, cholecystectomy for chronic chole- } \\
\text { cystitis }\end{array}$ \\
\hline R. D. & 60 & 78.4 & $E_{1}$ & Post-menopause & $\begin{array}{l}\text { T-tube drainage, cholecystectomy for chronic chole- } \\
\text { cystitis }\end{array}$ \\
\hline P. C. & 66 & 78.2 & $E_{1}$ & Post-menopause & $\begin{array}{l}\text { T-tube drainage, cholecystectomy for chronic chole- } \\
\text { cystitis }\end{array}$ \\
\hline E. H. & 49 & 60.0 & $E_{2}$ & Post-menopause & $\begin{array}{l}\text { T-tube drainage, cholecystectomy for hydrops of gall- } \\
\text { bladder with small cancer, diabetes mellitus, bilateral } \\
\text { oophorectomy and hysterectomy } 7 \text { years ago }\end{array}$ \\
\hline C. P. & 72 & 46.6 & $\mathrm{E}_{2}$ & Post-menopause & $\begin{array}{l}\text { T-tube drainage, cholecystectomy for hydrops of gall- } \\
\text { bladder, hysterectomy } 6 \text { months ago, diabetes mellitus }\end{array}$ \\
\hline
\end{tabular}

intravenously into 22 women: six normal females, two pregnant women in the last trimester, nine patients with cancer, and five women with bile-fistulas ( $T$-tube drainage). The clinical data related to these subjects are presented in Table I. All the subjects were in good nutritional status and none had evident renal or liver dysfunction or more than a mild anemia (hemoglobin concentrations not lower than $11 \mathrm{Gm}$. per cent), except where indicated. The $\mathrm{C}^{14}$-estrone or $\mathrm{C}^{14}$-estradiol was dissolved in 1 to $2 \mathrm{ml}$. of absolute ethanol and then diluted with 30 to $50 \mathrm{ml}$. of saline, which was injected intravenously over a period of 1 to 2 minutes. In two of the subjects (M.S. and M.K.), intravenous infusions of $100 \mathrm{mg}$. of the non-radioactive estrogens, dissolved in propylene glycol and human serum albumin (24) and then diluted with physiological saline, were given over a period of one hour. At the end of the infusion, the radioactive steroid was injected intravenously during a period of one minute. One patient (E.K.) was injected intramuscularly, with $500 \mathrm{mg}$. of an aqueous suspension of crystalline estrone over a period of five days $(20 \mathrm{mg}$. five times daily). On the fourth day, $5 \mu c$. of estrone were mixed with the injection mixture given at noon.

over 99 per cent of the radioactivity, determined in an Actigraph (Nuclear Chicago), were located in the areas corresponding to those of standard compounds.
Except for slight, intermittent nausea and mild swelling and pain in the breasts, none of these three subjects showed any untoward effects from the large doses of estrogens.

All the patients with $\mathrm{T}$-tube drainage of bile had normal liver function tests pre-operatively. The steroids

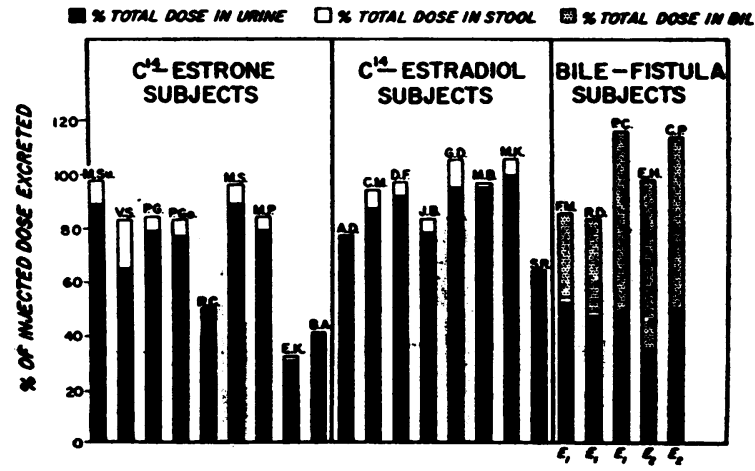

Fig. 1. The Percentage of Radionctivity Excreted IN THE Urine, Stool and Bile Following 16-C ${ }^{\text {Mit-Es- }}$ TRONe OR 16-C ${ }^{\text {H4}}$-Estradiol Administration

No stool collections were secured from subjects B.A., E.K., R.C., A.D. and S.R. Subject E.K. received the $\mathrm{C}^{36}$-estrone intramuscularly. 


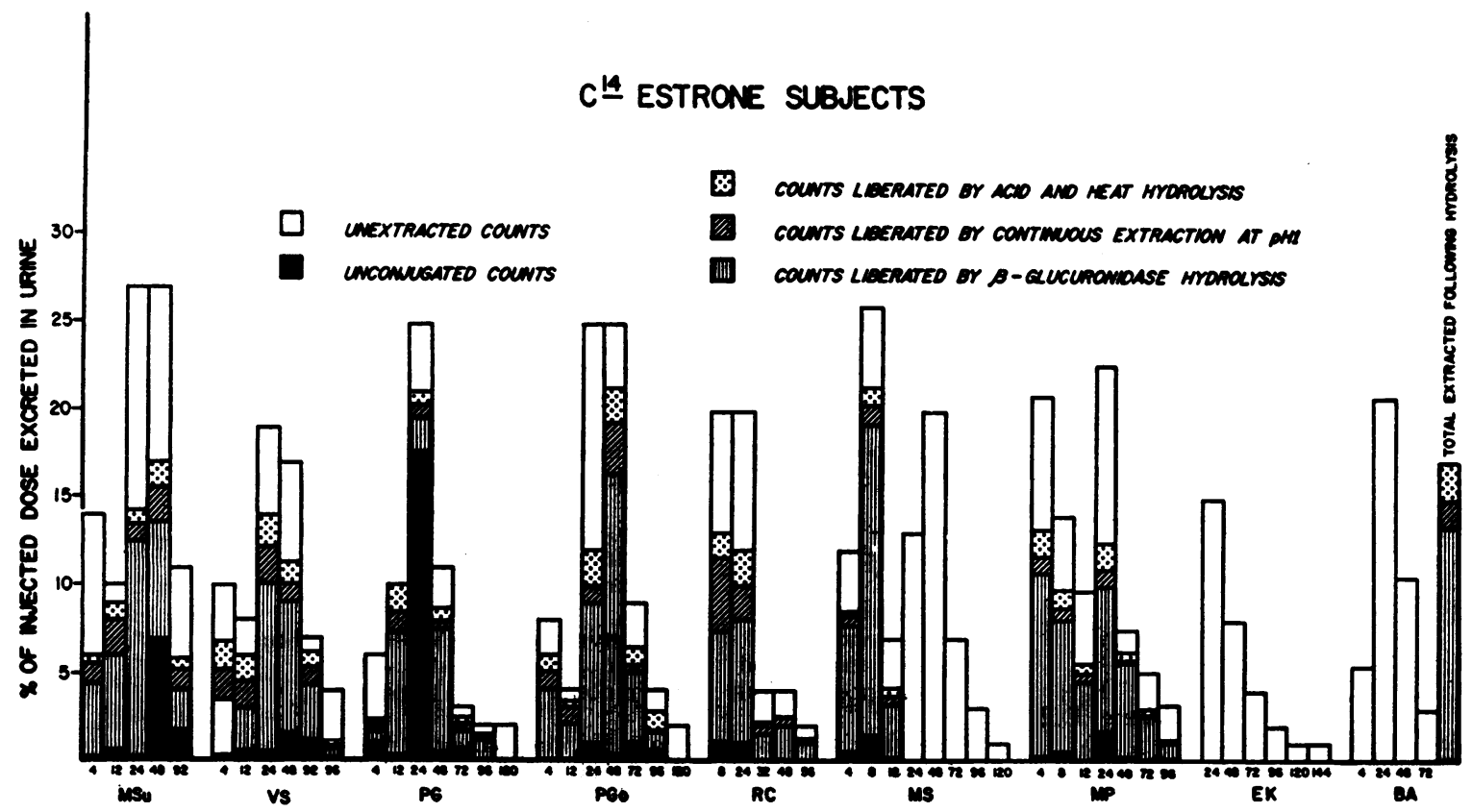

Fig. 2. Excretion of Radioactivity in the Urine Following the Injection of Ci4-Estrone

In this, and in the following figures, the numbers on the abscissa refer to the hour, following the injection of the $\mathrm{C}^{16}$ steroids, when the collection was terminated.

were injected after a patient's condition had become stabilized without fever or other complications, after oral intake of fluids and food had been established, and never sooner than three days post-operatively. Complete biliary collections were assured by a special suction apparatus and by the appearance of acholic stools during and after the period of study.

The methods for collection and processing of urine,

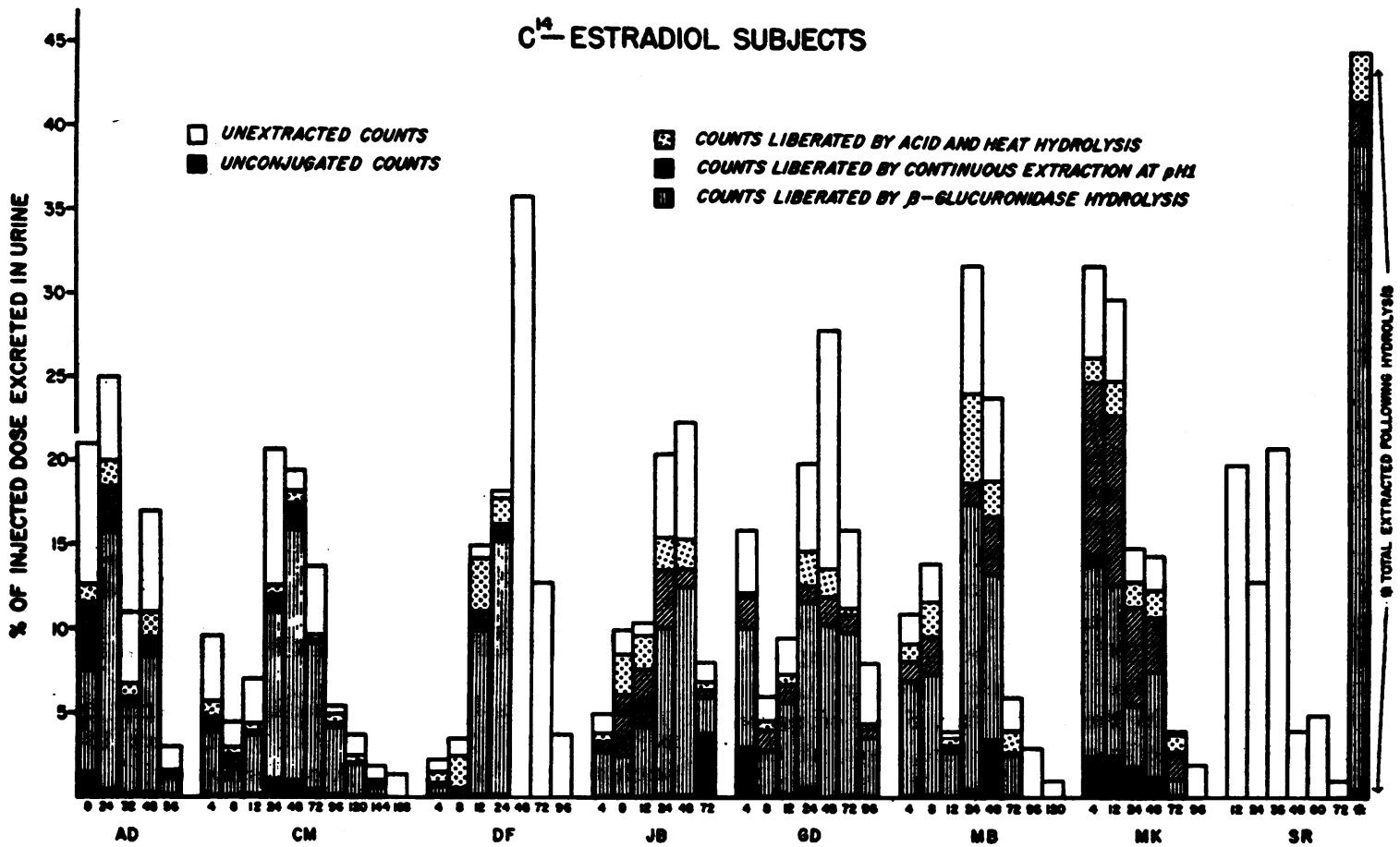

Fig. 3. Excretion of Radioactivity in the Urine Following the In Jection of Ci4-Estradiol 
bile and blood, the determination of radioactivity, and the various hydrolytic and extraction procedures have been described in a previous publication (25). One additional procedure was added in the latter part of the study. The determination of total radioactivity in the bile and urine samples was performed in a dual-channel liquid phosphor scintillation counter (TMC Model LP24). One ml. of urine or $0.2 \mathrm{ml}$. of bile was added to $10 \mathrm{ml}$. of a special mixture. The latter consisted of 1,500 $\mathrm{ml}$. of dioxane, $250 \mathrm{ml}$. of anisole, $250 \mathrm{ml}$. of ethylene glycol dimethyl ether, $30 \mathrm{Gm}$. of 2,5-diphenyloxazole and $1 \mathrm{Gm}$. 1,4-di-(2,4-diphenyloxazyl) benzene. The samples were then centrifuged and let stand in the dark, refrigerated chamber before being counted. An internal standard $\left(1 \mathrm{ml}\right.$. of a dilute solution of $\mathrm{C}^{14}$-acetic acid in the special mixture) was then added to each sample to determine the extent of "quenching." All samples were counted for a sufficient length of time to register at least 1,000 counts.

The plasma was separated from erythrocytes by centrifugation and the red cells washed twice with large volumes ( 50 to $150 \mathrm{ml}$.) of isotonic saline. Total radioactivity was extracted from erythrocytes by addition of absolute ethanol to the cells, centrifugation after standing overnight in the cold, and repetition of the extraction process. The alcohol was evaporated to dryness and the radioactivity determined in the sample.

The plasma protein residues, following the extraction

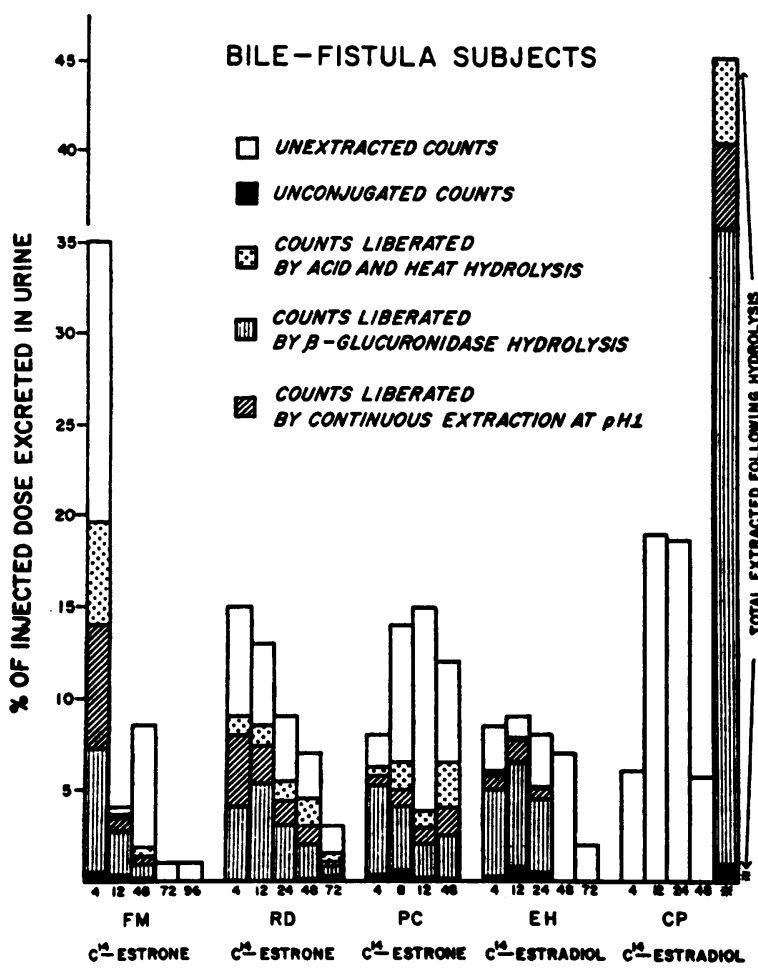

Fig. 4. Excretion of Radioactivity IN THE URINe of Subjects with Bile-Fistulas Following the INJECTION OF $\mathrm{C}^{14}$-ESTROGENS

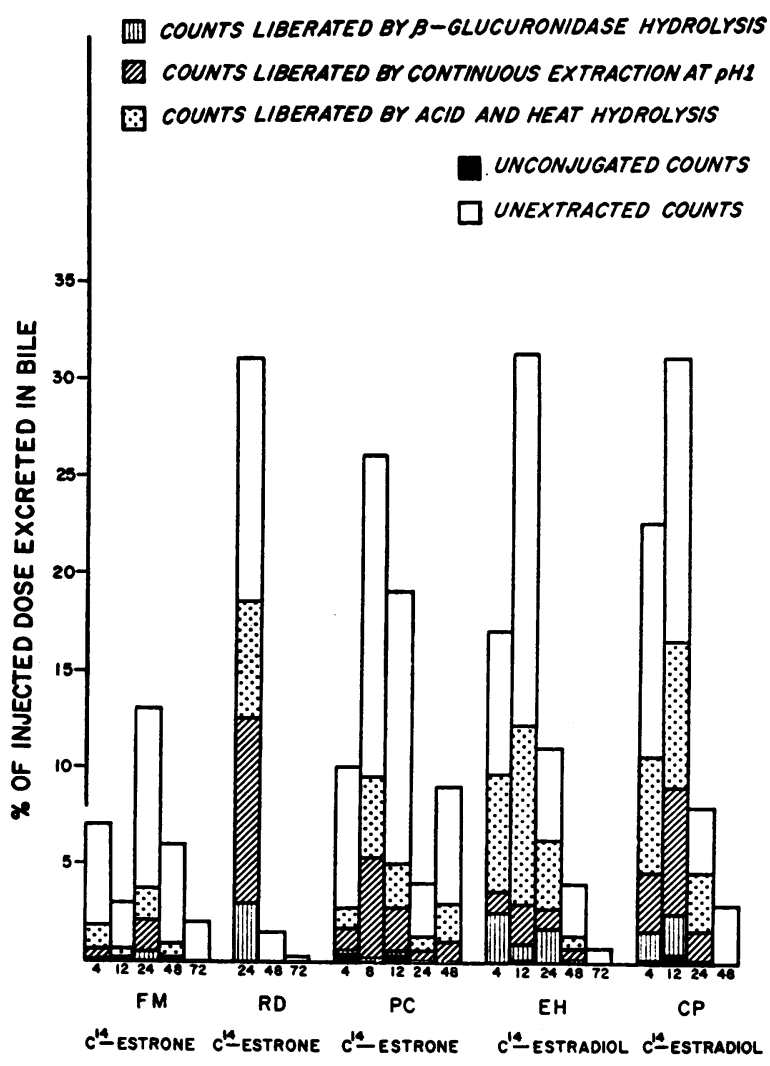

Fig. 5. Excretion of Radioactivity in the Bile of Five Subjects

Note that most of the extractable radioactive metabolites were released following hydrolysis at $\mathrm{pH} 1$ or by hot acid.

of the plasma with chloroform and then with absolute ethanol, were combined and digested in $0.1 \mathrm{~N} \mathrm{NaOH}$ over a steam-bath. The solution was then neutralized and extracted with ether.

Throughout this paper the word "unconjugated," or "free," will refer to steroids which are extractable with ether or chloroform before any of the specimens were hydrolyzed; the "glucuronidate fraction" to steroids which become extractable with ether or chloroform following hydrolysis with $\beta$-glucuronidase; and the "sulfate fraction" to steroids extracted continuously with ether for 48 hours at $\mathrm{pH} 1$.

\section{RESULTS}

The excretion of injected radioactivity in urine, feces and bile is shown in Figure 1. The amount excreted in the urine during the 96 to 120 hours following intravenous injection of $\mathrm{C}^{\mathbf{1 4}}$-estrone or $\mathrm{C}^{14}$-estradiol ranged (exclusive of the bile-fistula patients) from 41 to 109 per cent (average 80 per cent) of the injected dose. When the $\mathrm{C}^{14}$-estrone 


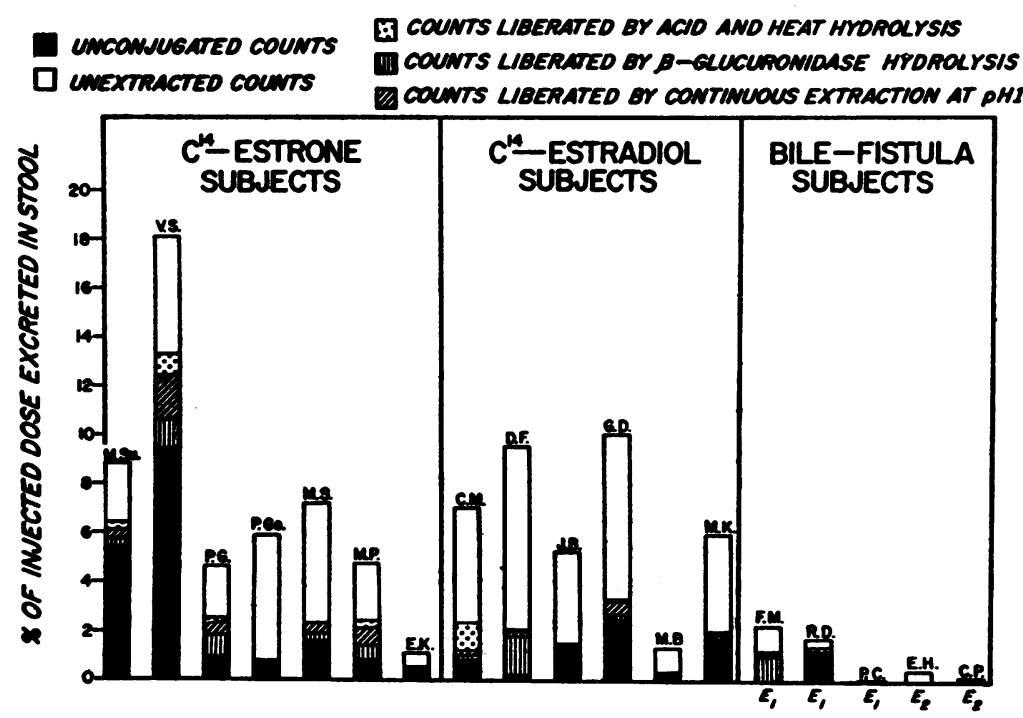

Fig. 6. Radionctivity Excreted in the Stools of Subjects Injected WITH C ${ }^{24}$-EstrogeNS

Note that most of the extractable radioactive metabolites occur in the unconjugated form.

was injected intramuscularly in a mixture with large amounts of estrone in an aqueous suspension, only 31 per cent of the radioactivity was excreted in the urine of Subject E.K. in 144 hours. The total radioactivity excreted in the urine of normal subjects did not differ significantly from that of patients with cancer. Of interest was the low excretion of radioactivity in the pregnant women, B.A. and S.R. The rate of excretion of radioactivity in the urine following the administration of $\mathrm{C}^{14}$-estrogens is shown in Figures 2 and 3. A comparison with the rates following the administration of other $\mathrm{C}^{14}$-steroids (25-31) indicates much slower excretion of radioactivity in the urine following $\mathrm{C}^{14}$-estrogen administration than those following other $\mathrm{C}^{14}$-steroids. This was particularly marked following $\mathrm{C}^{14}$-estradiol administration when radioactivity was excreted in the urine as late as 4 to 5 days after intravenous injection.

The urinary excretion of total radioactivity during certain time periods following injection is shown in Figures 2, 3, and 4, as well as the amounts of steroid metabolites extractable following various hydrolytic procedures. It is apparent that a preponderant part of the injected $\mathrm{C}^{14}$-estrone or $\mathrm{C}^{14}$-estradiol is excreted in conjugated form, primarily as the glucuronidate. Except for a few urine samples where, for some reason as yet unknown, large amounts of free metabolites were present, unconjugated steroids were present in very small amounts (less than 4 per cent). Sulfate-conjugated metabolites of $\mathrm{C}^{\mathbf{1 4}}$-estrone or $\mathrm{C}^{\mathbf{1 4}}$ estradiol constituted, in general, an unimpressive part of extractable metabolites in the urine. An insignificant part of the radioactivity was extracted from the urine after strong acid hydrolysis. On the average, about 72 per cent of the counts in the urine were extractable following the various hydrolytic procedures, the highest percentage (79 per cent) being extracted from urines of patients receiving estradiol.

Patients with bile-fistulas excreted 35 to 52 per cent (average 47 per cent) of the injected radioactivity in the urine (Figure 4 ). The amount of radioactivity excreted during the initial 12 hours was similar to that seen in non-fistula patients. Following that period, however, the urinary excretion of radioactivity was much less than in the other subjects of the study. It should be pointed out that the bile-fistula patients constituted a mixed group: three injected with $\mathrm{C}^{14}$-estrone and two with $\mathrm{C}^{14}$-estradiol. The amount of radioactive metabolites extractable from the urines of the bile-fistula patients was similar to that of the total group, i.e., the largest amount being pres- 
ent as the glucuronidate and the smallest as free.

The amount of radioactivity excreted in the bile is shown in Figure 5. The excretion ranged from 31 to 68 per cent (average 52 per cent) and occurred primarily during the first 12 hours. It is interesting to note that most of the extractable metabolites were liberated either with continuous extraction at $\mathrm{pH} 1$ or by hot acid. The amounts of free and glucuronidate metabolites were small. This contrasts with the pattern present in the urine. In addition, a larger percentage of the counts in the bile ( 59 per cent) was non-extractable after hydrolysis as compared to the urine (36 per cent).

The radioactivity excreted in the stools (Figure 6) of non-fistula patients varied from 1 to 18 per cent (average 7 per cent). In the patients with $\mathrm{T}$-tube drainage, the fecal radioactivity excreted ranged from 0 to 2.2 per cent (average 0.9 per cent). Most of the extractable radioactivity in the stool was present in the free form.

The clearance of free radioactive steroids from

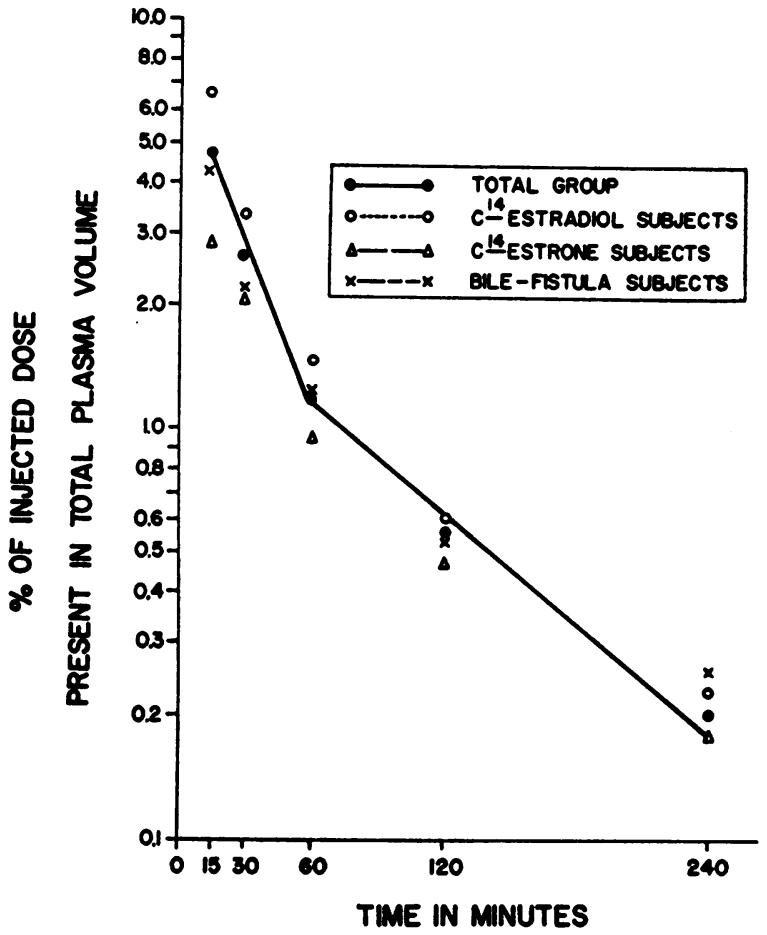

Fig. 7. The Clearance of "Free Steroim" Radioactivity from the Plasma Following the IntraveNous InJection of $C^{\mathbf{4}}$-Estrone or $\mathbf{C}^{\mathbf{4}}$-Estradiol

Note initial rapid rate and subsequent slower rate of clearance.
TABLE II

Radioactivity levels in the free steroid fraction of plasma following injection of 16-C 14-estrone or 16-C $C^{14}$-estradiol*

\begin{tabular}{|c|c|c|c|c|c|}
\hline \multirow[b]{2}{*}{ Subject } & \multicolumn{5}{|c|}{$\%$ of injected doee present in total plasma volume } \\
\hline & $15 \mathrm{~min}$. & $30 \mathrm{~min}$. & $60 \mathrm{~min}$. & $120 \mathrm{~min}$. & $240 \mathrm{~min}$. \\
\hline \multicolumn{6}{|c|}{ Cu-estrone } \\
\hline $\begin{array}{l}\text { M. Su. } \\
\text { V.S. } \\
\text { P. G. } \\
\text { M. S. } \\
\text { M. P. } \\
\text { B. A. } \\
\text { F. M. } \\
\text { R. D. } \\
\text { P. C. }\end{array}$ & $\begin{array}{l}3.4 \\
2.5 \\
2.5 \\
5.0 \\
1.8 \\
\\
2.1 \\
2.6 \\
3.2\end{array}$ & $\begin{array}{l}2.4 \\
1.5 \\
2.4 \\
4.3 \\
0.9 \\
3.0 \\
1.2 \\
0.8 \\
2.1\end{array}$ & $\begin{array}{l}1.2 \\
0.7 \\
0.9 \\
2.2 \\
0.3 \\
0.9 \\
0.5 \\
0.7 \\
0.9\end{array}$ & $\begin{array}{l}0.5 \\
0.4 \\
0.4 \\
1.2 \\
0.1 \\
0.4 \\
0.2 \\
0.4 \\
0.5\end{array}$ & $\begin{array}{l}0.2 \\
0.2 \\
0.2 \\
0.2 \\
0.0 \\
0.3 \\
0.1 \\
0.0 \\
0.4\end{array}$ \\
\hline \multicolumn{6}{|c|}{ Cu-estradiol } \\
\hline $\begin{array}{l}\text { C. M. } \\
\text { D. F. } \\
\text { J. B. } \\
\text { G. D. } \\
\text { M. B. } \\
\text { M. K. } \\
\text { E. H. } \\
\text { C. P. }\end{array}$ & $\begin{array}{l}5.7 \\
7.8 \\
8.2 \\
6.9 \\
4.9 \\
6.3 \\
9.4 \\
4.5\end{array}$ & $\begin{array}{l}3.1 \\
3.1 \\
4.3 \\
3.5 \\
2.0 \\
3.8 \\
4.5 \\
2.2\end{array}$ & $\begin{array}{l}0.8 \\
0.9 \\
1.5 \\
1.6 \\
1.2 \\
2.0 \\
2.6 \\
1.3\end{array}$ & $\begin{array}{l}0.4 \\
0.6 \\
0.6 \\
0.6 \\
0.4 \\
0.7 \\
0.8 \\
0.8\end{array}$ & $\begin{array}{l}0.0 \\
0.1 \\
0.1 \\
0.4 \\
0.1 \\
0.2 \\
0.6 \\
0.3\end{array}$ \\
\hline
\end{tabular}

* In this, and the following tables, the number of counts present in samples representing values less than 1 were of such magnitude that their counting did not involve a standard error from the mean greater than 5 per cent; in samples representing values less than 0.5 the counting did not involve a standard error from the mean greater than 10 per cent.

the plasma of the injected subjects is shown in Figure 7 and Table II. For the sake of comparison and uniformity, it was assumed that each subject's blood volume constituted 9 per cent of his body weight, with 5 per cent as the plasma volume and 4 per cent as the total red blood cell mass. The results are expressed as the percentage of the injected radioactivity present in the total plasma volume or red cell mass. From Figure 7 it can be seen that the free steroids were cleared from the plasma at two different rates, with half-lives of approximately 20 and 70 minutes. Even though the radioactivity in the free steroid fraction tended on the average to be lower (but not statistically different) following $\mathrm{C}^{14}$-estrone administration than that following $\mathrm{C}^{14}$-estradiol injection, the clearance rates were nearly identical. The presence of a bile-fistula had no effect upon the level of radioactive free steroid. Negligible radioactivity was present in the free steroid fraction eight hours following injection and none could be demonstrated 24 hours later. In Figure 8 and Table III are shown steroid glucuronidate plasma 


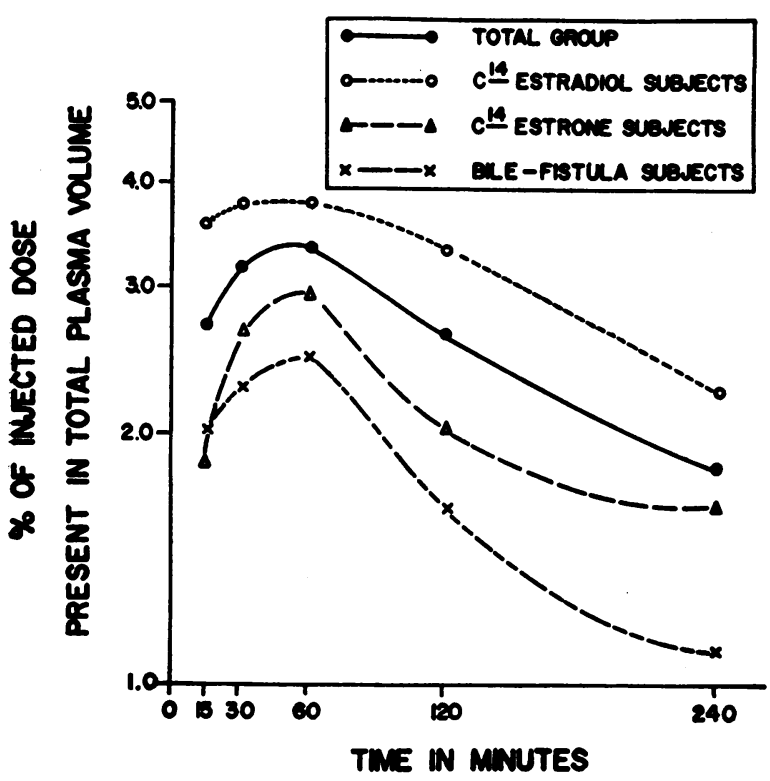

Fig. 8. Radioactive Glucuronidate Sterom Levels in the Plasma Following the Administration of RAdIOACTIVE ESTRONE OR Estradiol INTRAVENOUSLY

levels. Within 30 minutes following injection of the $\mathrm{C}^{14}$-estrogens, the radioactivity in the plasma "glucuronidate fraction" exceeded that present in the unconjugated fraction. Activity declined slowly thereafter. In contrast to the radioactivity in the free steroid fraction, a significant number

TABLE III

Radioactivity levels in steroid glucuronidate fraction of plasma following injection of 16-C $C^{\text {14-estrone }}$ or 16-C $C^{14}$-estradiol

\begin{tabular}{|c|c|c|c|c|c|}
\hline \multirow[b]{2}{*}{ Subject } & \multicolumn{5}{|c|}{$\%$ of injected dose present in total plasma volume } \\
\hline & $15 \mathrm{~min}$. & $30 \mathrm{~min}$. & $60 \mathrm{~min}$. & $120 \mathrm{~min}$. & $240 \mathrm{~min}$. \\
\hline \multicolumn{6}{|c|}{$C^{14}$-estrone } \\
\hline $\begin{array}{l}\text { M.Su. } \\
\text { V.S. } \\
\text { P. G. } \\
\text { M. S. } \\
\text { M. P. } \\
\text { B. A. } \\
\text { F. M. } \\
\text { R. D. } \\
\text { P. C. }\end{array}$ & $\begin{array}{l}0.8 \\
1.1 \\
1.4 \\
4.2 \\
1.9 \\
\\
\\
1.4 \\
2.2 \\
1.8\end{array}$ & $\begin{array}{l}1.3 \\
1.5 \\
1.9 \\
5.5 \\
2.5 \\
3.6 \\
2.1 \\
3.1 \\
2.2\end{array}$ & $\begin{array}{l}2.4 \\
2.6 \\
2.9 \\
4.5 \\
1.6 \\
4.3 \\
1.9 \\
4.1 \\
2.4\end{array}$ & $\begin{array}{l}1.8 \\
2.1 \\
1.6 \\
4.0 \\
0.8 \\
2.5 \\
0.8 \\
2.5 \\
2.0\end{array}$ & $\begin{array}{l}1.3 \\
2.3 \\
1.1 \\
1.5 \\
0.4 \\
1.8 \\
1.2 \\
0.8 \\
1.6\end{array}$ \\
\hline \multicolumn{6}{|c|}{$C^{14}$-estradiol } \\
\hline $\begin{array}{l}\text { C. M. } \\
\text { D. F. } \\
\text { J. B. } \\
\text { G. D. } \\
\text { M. P. } \\
\text { M. K. } \\
\text { E. H. } \\
\text { C. P. }\end{array}$ & $\begin{array}{l}0.8 \\
2.6 \\
3.8 \\
4.8 \\
4.3 \\
7.2 \\
2.8 \\
2.0\end{array}$ & $\begin{array}{l}0.8 \\
2.7 \\
4.1 \\
6.6 \\
7.8 \\
5.1 \\
2.1 \\
1.9\end{array}$ & $\begin{array}{l}0.9 \\
3.4 \\
4.5 \\
3.4 \\
9.2 \\
4.9 \\
2.0 \\
1.9\end{array}$ & $\begin{array}{l}1.7 \\
5.7 \\
6.0 \\
3.3 \\
3.7 \\
3.4 \\
0.6 \\
2.0\end{array}$ & $\begin{array}{l}2.3 \\
2.2 \\
3.4 \\
4.8 \\
1.3 \\
2.4 \\
0.9 \\
1.0\end{array}$ \\
\hline
\end{tabular}

TABLE IV

Radioactivity levels in steroid sulfate fraction of plasma following injection of 16-Ci4-estrone or 16-C14-estradiol

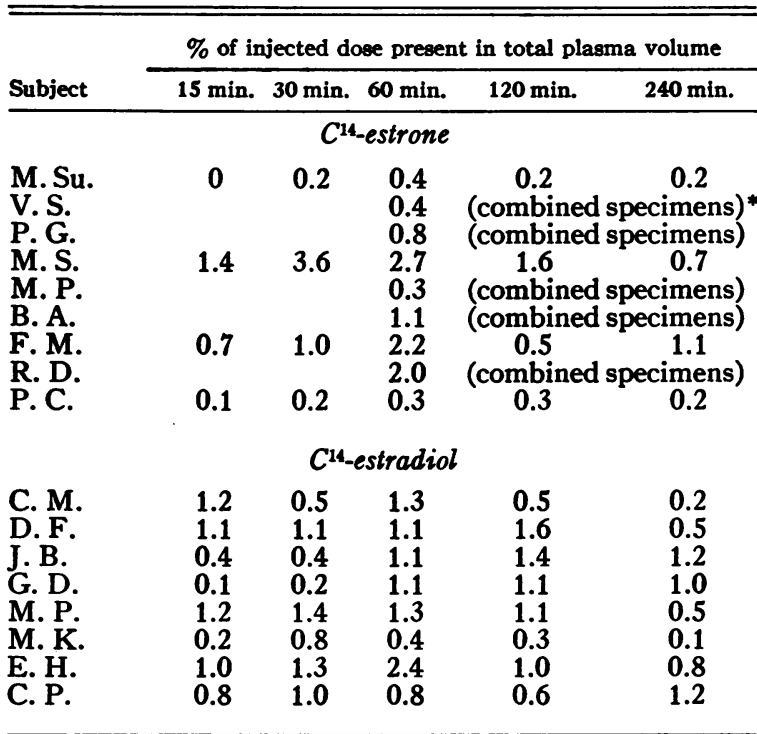

* The values shown for the "combined specimens" refer to the radioactivity present in the pooled plasma samples obtained from the five blood samples drawn from each patient.

of counts was present in the glucuronidate fraction as late as one to two days after the injection of the $\mathrm{C}^{14}$-estrogen, particularly $\mathrm{C}^{14}$-estradiol. For example, Subject G.D. had 3.5 and 1.4 per cent of the injected radioactivity in the total plasma volume 24 and 48 hours, respectively, following the injection. Patient J.B. had 1 and 0.5 per cent 24 and 48 hours, respectively, following the injection of $\mathrm{C}^{14}$-estradiol. It is interesting to note, again, that the radioactivity in the glucuronidate fraction following $\mathrm{C}^{14}$-estrone administration was lower than that following $\mathrm{C}^{14}$-estradiol injection. On the other hand, the levels in the plasma of the biliary fistula patients were the lowest of the group.

The counts present in the plasma "sulfate fraction" are shown in Table IV. The levels were on the average one-third to one-tenth as high as those in the glucuronidate fraction. In some subjects (F.M., M.S., C.M. and E.H.), however, the radioactivity in the sulfate fraction approached that present in the glucuronidate fraction of these patients.

The radioactivity present in the plasma fractions following hydrolysis by strong acid and heat 
was negligible. The radioactivity associated with the red blood cells is shown in Figure 9 and Table V. It should be pointed out that the radioactivity extracted from the erythrocytes represents the total number of counts without subsequent hydrolytic procedures. From the data it can be seen that substantial radioactivity may be associated with the red blood cells, although the amount was much lower than that present in the plasma.

The radioactivity present in the protein residues is shown in Table V. Since the calculations are based upon the counts present in the combined protein residues, the results are only a rough approximation of the radioactivity associated with the plasma proteins. In general, the radioactivity associated with the proteins tended to be rather low in comparison with the radioactivity extracted from the plasma.

\section{DISCUSSION}

It is apparent from the data presented that the preponderant part of the radioactivity of $\mathrm{C}^{14}$ estrone or $\mathrm{C}^{14}$-estradiol is excreted in the urine. Our findings are similar to those of Beer and Gallagher $(17,18)$, who recovered about 65 per cent of the radioactivity in the urine following intravenous or intramuscular injection of radioactive estrone or estradiol. These findings contrast markedly with the results obtained in the past using large and unphysiological amounts of nonradioactive estrogens. Thus, following injection of $25 \mathrm{mg}$. or more of estrone or estradiol, usually less than 20 per cent was recovered in the urine as the three known estrogens (estrone, estradiol, or estriol) $(1-6,32)$. Without knowledge of all the metabolites of estrone or estradiol, it was impossible to determine how much of the injected

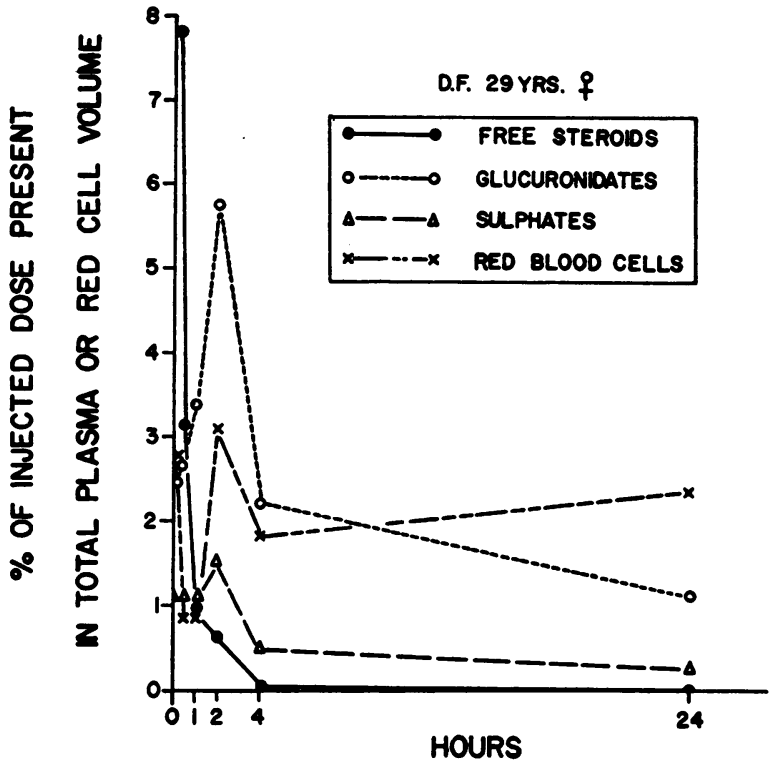

Fig. 9. Comparison of the Total Radioactivity Levels Present in the Erythrocytes to Those Present in the Plasma Free, Glucuronidate and Sulphate Fractions of Subject D.F. Following the Injection of C ${ }^{14}$-Estradiol.

steroid appeared in the urine in some other form. The introduction of $\beta$-glucuronidase hydrolysis has resulted in the liberation of more extractable free phenolic metabolites following estrogen administration than was possible in the past (17). Labelling of the estrogens with carbon-14 makes it possible to measure recoveries more precisely than with chemical or bioassay techniques.

In our studies about 45 per cent of the radioactivity were extractable from the urine following $\beta$-glucuronidase hydrolysis. Somewhat higher values (about 60 per cent) were obtained by Beer and Gallagher $(17,18)$. It is possible that in our

TABLE V

Total radioactivity levels associated with the erythrocytes and plasma proteins following injection of 16-C $C^{14}$-estrone or 16-C $C^{14}$-estradiol

\begin{tabular}{|c|c|c|c|c|c|c|c|c|c|c|}
\hline \multirow[b]{2}{*}{ Subject } & \multicolumn{9}{|c|}{$\%$ of dose present in total red cell volume } & \multirow{2}{*}{$\begin{array}{c}\text { \% associated } \\
\text { with proteins } \\
\text { (combined } \\
\text { samples) }\end{array}$} \\
\hline & 15 min. & $30 \mathrm{~min}$. & $1 \mathrm{hr}$. & $2 \mathrm{hr}$. & $4 \mathrm{hr}$. & $8 \mathrm{hr}$. & $12 \mathrm{hr}$. & $24 \mathrm{hr}$. & $48 \mathrm{hr}$. & \\
\hline $\begin{array}{l}\text { M. S. } \\
\text { M. K. } \\
\text { M. B. } \\
\text { M. P. } \\
\text { B. A. } \\
\text { G. D. } \\
\text { J. B. } \\
\text { D. F. }\end{array}$ & $\begin{array}{l}2.3 \\
2.7 \\
0.5 \\
0.5 \\
\\
1.1 \\
0.9 \\
2.8\end{array}$ & $\begin{array}{l}0.6 \\
2.4 \\
0.3 \\
0.7 \\
0.2 \\
0.9 \\
1.4 \\
0.7\end{array}$ & $\begin{array}{l}0.3 \\
1.8 \\
0.2 \\
0.8 \\
0.2 \\
0.4 \\
0.6 \\
0.7\end{array}$ & $\begin{array}{l}0.2 \\
0.8 \\
0.1 \\
0.8 \\
0.1 \\
0.9 \\
1.6 \\
3.1\end{array}$ & $\begin{array}{l}0.4 \\
0.7 \\
0.1 \\
0.7 \\
0.1 \\
0.2 \\
2.3 \\
1.9\end{array}$ & $\begin{array}{l}0.5 \\
0.6 \\
3.3\end{array}$ & 0.1 & $\begin{array}{l}0.2 \\
0.1 \\
0.0\end{array}$ & $\begin{array}{l}0.4 \\
0.6\end{array}$ & $\begin{array}{l}0.4 \\
0.9 \\
2.1 \\
0.5 \\
0.4 \\
0.5 \\
1.0\end{array}$ \\
\hline
\end{tabular}


study the re-incubation of urine with $\beta$-glucuronidase could have resulted in further liberation of metabolites. In some of the urine specimens it was indeed demonstrated that an additional 10 to 20 per cent of the radioactivity become extractable following such re-incubation. In addition, it is possible that the incubation of the urine with $\beta$-glucuronidase for longer periods of time, such as employed by Beer and Gallagher (120 hours), than used in our experiments ( 48 hours) may result in a greater percentage of extractable counts. Beer and Gallagher, in addition, demonstrated that following the injection of $\mathrm{C}^{14}$-estrone or $\mathrm{C}^{14}$ estradiol 8 to 10 per cent of the radioactivity in the urine were present as estrone and 11 to 31 per cent were present as estriol. Even though the recent identification of new metabolites $(23,33$ 35 ) of estrone and estradiol has enlarged our knowledge of the metabolism of these steroids, a significant part of the metabolites of the injected estrogens remains unknown, especially those remaining in the urine following the various hydrolytic and extraction procedures.

Intravenous injection of large amounts of estrone or estradiol with the radioactive steroids did not affect the rate of their excretion. On the other hand, the intramuscular administration of a suspension of crystalline estrone with $\mathrm{C}^{14}$-estrone resulted in only 31 per cent excretion of the radioactivity in the urine over a period of many days. Beer and Gallagher (18) found 65 and 72 per cent of the radioactivity in the urine following the intramuscular injection of $\mathrm{C}^{14}$-estradiol with large amounts of carrier steroid, and 65 per cent following oral ingestion. The discrepancy between the results in our Subject E.K., and those of Beer and Gallagher may be due to the fact that these authors administered the steroid in solution in benzyl alcohol and sesame oil, whereas Subject E.K. was injected with an aqueous suspension of estrone resulting in slower absorption of the steroid.

Radioactivity is excreted much more slowly following $\mathrm{C}^{14}$-estrone or $\mathrm{C}^{14}$-estradiol administration than that following other $\mathrm{C}^{14}$-steroids. Similar observations were made by Beer and Gallagher $(17,18)$. Thus, following $C^{14}$-labelled cortisol (27-29), testosterone $(25,26), 11 \beta$-hydroxyandrostenedione $(31,36)$ or corticosterone $(30)$ administration, over one-third of the radioactivity is excreted in the urine in the first four hours and over 60 to 70 per cent in the first 12 hours. On the other hand, following $\mathrm{C}^{14}$-estrone or $\mathrm{C}^{14}$ estradiol administration, only 12 per cent are excreted in the first four hours and about 33 per cent after 12 hours. Following the administration of the former steroids, radioactivity excretion in the urine is usually essentially complete in $\mathbf{4 8}$ hours, whereas following $\mathrm{C}^{14}$-estrone or $\mathrm{C}^{14}$-estradiol significant radioactivity was being excreted as late as 96 to 120 hours after the administration of the steroids intravenously.

Even though, in general, the importance of the biliary excretion of estrogens and their enterohepatic circulation had been accepted in the past to be true for animals, e.g., dogs, cows $(6,37)$, such has not been the case for human subjects. Our data demonstrate, however, that not only was more of the radioactivity of $\mathrm{C}^{14}$-estrone or $\mathrm{C}^{14}$ estradiol excreted in the bile than that seen following the injection of any other known steroid in human subjects $(25,28-30,38)$, but in addition more of the radioactivity appeared in the bile than in the urine of three of the bile-fistula subjects. This establishes the importance of biliary excretion in the metabolism of estrogens in women. The importance of the biliary route of excretion of estrogens is in accord with the earlier findings in dogs and in pregnant women (9-14). Similar results were obtained by Albert, Heard, Leblond, and Saffran in animals using I'181-labelled estradiol (16). In addition, Twombly and Schoenewaldt (15) demonstrated considerable excretion of radioactivity in the bile of human subjects following the injection of estrone labelled with radioactive bromine. Since the introduction of a halogen into the steroid molecule may affect its metabolism in an unknown fashion, it is difficult to compare these results with those obtained using $\mathrm{C}^{14}$ labelled naturally occuring estrogens.

The large excretion of radioactivity in the bile following $\mathrm{C}^{14}$-estrogen administration is at variance with results obtained by others when excretion of non-labelled estrogens was studied in human subjects $(39,40)$. This is not surprising since even with labelled $\mathrm{C}^{14}$-estrone and $\mathrm{C}^{14}$ estradiol only about 40 per cent of the radioactivity could be released and extracted from the bile following various hydrolytic procedures. In addition, the estimation of the biliary excretion of 
metabolites following non-radioactive administration depended on biological assay or determination of a few known estrogen metabolites. Neither procedure can estimate all the metabolites of estrogens in the bile. Thus, although Rubin, Dorfman and Miller (39) found at least a 30-fold increase in the urinary and an 8- to 10-fold increase in biliary excretions of the three naturally occuring estrogens following the administration of $200 \mathrm{mg}$. of estradioldipropionate, the total recovery was very small. Somewhat similar findings were observed by Stimmel (40).

In contrast to the findings in the bile of animals, where the estrogens occur in unconjugated form, almost all of the estrogen metabolites present in human bile were in conjugated form. In addition, the percentage of glucuronidate conjugated metabolites was small when compared to similar metabolites in the urine. Most of the extractable metabolites in the bile were released by hydrolysis at $\mathrm{pH} 1$ (with continuous ether extraction) and by hot acid. It should be pointed out that most of the radioactivity in the bile was not extractable following all hydrolytic and extraction procedures.

Since, on the average, only about 7 per cent of the radioactivity appeared in the stool of the non-fistula patients, it is apparent that a considerable reabsorption of estrogen metabolites excreted in the bile must occur in the gastrointestinal tract. In addition, patients with bile-fistulas excreted negligible amounts of radioactivity in the stools. The small amounts that were present may possibly be due to escape of small amounts of bile or to the excretion of steroid metabolites in the gastrointestinal juices. It was interesting to note that most of the extractable radioactivity in the stools was in the free form. Since the steroids occur in the bile in conjugated form, it is possible that the free steroids present in the stool are due to the $\beta$-glucuronidase and phenolsulfatase activities of the feces. Such activities have been demonstrated by several observers $(28,41)$.

Radioactive estrone or estradiol was cleared from the plasma rapidly and at somewhat faster rates than the free steroid clearance following the administration of $\mathrm{C}^{\mathbf{1 4}}$-cortisol or $\mathrm{C}^{14}$-testosterone $(25,29)$. In addition, there was no significant difference in the clearance of the free steroids among the various subjects studied. The clearance of the free steroids from the plasma occurred

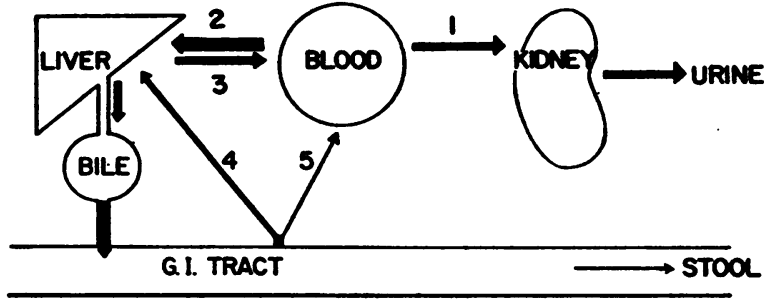

Fig. 10. Schematic Representation of the Various Possible Pathways of Estrogen Metabolism in Human Subjects

The thickness of the arrows indicates roughly the quantity of steroid metabolites involved in the metabolic pathway.

at two different rates, an initial fast rate with a half-life of approximately 20 minutes, which is probably due to mixing of the free steroid within a body pool, and a slower rate, with a halflife of approximately 70 minutes, which probably represents the true metabolic clearance of the free steroid metabolites. The conjugates of the radioactive estrogens reached their peak of radioactivity within 30 minutes and declined slowly thereafter. Following the initial 15 to 30 minutes, the levels of the glucuronidate markedly exceeded those of the free steroids. In addition, no free steroid radioactivity was demonstrable 24 hours following the injection of the radioactive estrogens. On the other hand, substantial radioactivity in the conjugated fractions was demonstrable as late as 48 to 72 hours following the injection. Of importance was the demonstration that the conjugated steroids in the plasma of patients with bile-fistulas tended to be the lowest of the group.

Based on the data of the present experiments and those published in the papers cited, a clearer picture of the metabolic fate and the importance of the hepato-biliary-enteric circulation in the metabolism of administered radioactive estrogens in human subjects can now be advanced. The metabolic pathways of estrogen metabolism are schematically represented in Figure 10. Following injection of radioactive estrone or estradiol a certain amount (usually one-third) is excreted in the urine conjugated with glucuronic acid. This excretion occurred within the first 24 hours following administration and was evident not only in the non-fistula patients but also in the patients with T-tube drainage. About one-third to over 
one-half of the radioactivity of the administered estrogens appeared in the bile, mostly as conjugates which are still unknown. We would like to advance the hypothesis that the conjugates are split in the gastrointestinal tract and then reabsorbed, as indicated by arrow 4 in Figure 10 . Following reabsorption, some of the metabolites are conjugated again in the liver with glucuronic acid and excreted in the urine, but the preponderant part is reconjugated and re-excreted in the bile to repeat the cycle just described. It is possible that a small amount of metabolites reabsorbed from the gastrointestinal tract escapes conjugation by the liver and enters the circulation to be excreted free in the urine. This is indicated by arrows 5 and 1 in Figure 10. The fact that glucuronidate-conjugated estrogens are not excreted appreciably in the bile, in contrast to the excretion in the urine, lends further support to the hypothesis that the metabolites which appear in the bile must be hydrolyzed in the gastrointestinal tract and reabsorbed as unconjugated steroids, which upon re-entry into the liver are conjugated with glucuronic acid, and are excreted in the urine. An alternate hypothesis would have the steroid metabolites absorbed from the gastrointestinal tract as conjugates, which in the liver under dynamic equilibrium are partially converted to a different type of conjugate.

This continuous recirculation of the metabolites of estrone and estradiol through the liver to the bile and the gastrointestinal tract and the excretion of a certain small percentage of this reabsorbed material in the urine accounts for the slow and delayed excretion in the urine of the radioactivity following the administration of $\mathrm{C}^{14}$-estrone

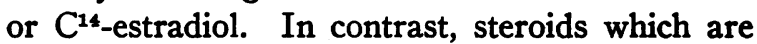
excreted rapidly in the urine are minimally excreted in the bile. This has been demonstrated to be true for such steroids as cortisol, cortisone, $11-\beta$-hydroxyandrostenedione and testosterone. The re-entry of metabolites through the gastrointestinal tract into the general circulation probably accounts for the persistence of high levels of glucuronidated metabolites in the plasma of the subjects studied. In addition, the low levels of plasma glucuronidated steroids in the T-tube drainage patients are probably due to failure of reabsorption of the steroids present in the bile (Figure 8).
The postulate was advanced by Beer and Gallagher $(17,18)$ that the slow urinary excretion of radioactivity following $\mathrm{C}^{14}$-estrogen administration, as compared to the excretion following other $\mathrm{C}^{14}$-steroid injections, e.g., testosterone, is related to the binding of the estrogens and their metabolites to plasma and liver proteins $(42,43)$ with resultant retardation of their renal excretion. In addition, these authors felt that the "relatively minor excretion of estrogen metabolites in the feces is suggestive that biliary and intestinal elimination played but minor roles in the metabolism of the estrogen by human subjects." These authors did not present data, however, on biliary excretion of radioactivity following administration of $\mathrm{C}^{14}$ estrogens. The results of our experiments do not support either of their concepts. We have previously been able to demonstrate that those steroids which are most avidly bound to human plasma proteins have a substantial biliary elimination, whereas those least bound were excreted insignificantly in the bile (44). As in the present study, it was shown that the exclusion of the bile from the gastrointestinal tract results in rapid excretion of radioactivity in the urine. Thus, nearly all of the radioactivity following the injection of $\mathrm{C}^{14}$-estrone or $\mathrm{C}^{14}$-estradiol appeared in the urine and bile within 24 hours. Of the radioactivity excreted in the urine almost 90 per cent appeared in the urine in 24 hours and over 60 per cent in the first 12 hours, in contrast to 60 per cent and 35 per cent, respectively, in the nonfistula group. It should be pointed out that the results of studies indicate avid binding of the estrogenic conjugates to human plasma proteins (44), but the exact role that this binding plays in the rate of urinary excretion of estrogenic metabolites awaits more conclusive and extensive studies.

The appearance of about 7 per cent of radioactivity in the feces, an amount equivalent to that found by Beer and Gallagher in their studies (17, 18 ), indicates that reabsorption from the gastrointestinal tract of the biliary metabolites may not be complete under normal circumstances, since less than 1 per cent of radioactivity appeared in the feces of patients with bile-fistulas. Since negligible radioactivity is present in the unconjugated fraction in the bile, one would predict that the clearance of the free steroids from patients with 
T-tube drainage would resemble that seen in patients without fistulas. That such is the case is demonstrated in Figure 7 . The clearance of the free steroids from the plasma of patients with bile-fistulas was almost identical to that of the total group.

The association of radioactivity with the red blood cells would appear to indicate that a significant percentage of endogenous or injected estrone or estradiol and their metabolites are associated with the erythrocytes $(20-22,45)$. The bulk of the radioactivity was present in the plasma, however. Our findings are at variance with previously published reports in which more estrogenic activity was found in the red blood cells than in the plasma $(20,21)$. The nature of the metabolites associated with the red blood cells and the effects of these cells on the metabolism of estrogens is a subject which deserves further study.

\section{SUMMARY}

$\mathrm{C}^{14}$-estrone and $\mathrm{C}^{14}$-estradiol have been injected intravenously into 22 women. A little over 80 per cent of the administered radioactivity were excreted in the urine during the 96 to 120 hours following the injection of these steroids. On the average, 72 per cent of the counts in the urine were extractable folowing various hydrolytic procedures, with the preponderant part being present in the glucuronidate form. About 50 per cent of the radioactivity administered appeared in the bile, collected through $\mathrm{T}$-tube drainage, mostly as conjugates released by hydrolysis at $\mathrm{pH} 1$ or by the hot acid. Approximately 7 per cent of the radioactivity appeared in the stools of non-fistula patients, indicating gastrointestinal reabsorption of metabolites excreted in the bile. The radioactive steroids were cleared from the plasma rapidly with at least two separate rates having half-lives of approximately 20 and 70 minutes, respectively. The conjugated metabolites of $\mathrm{C}^{14}$-estrone and $\mathrm{C}^{14}$-estradiol reached their peak in the plasma within 15 to 30 minutes following the injection of the steroids and retained high levels for as long as three days. The levels of the conjugated steroids in the plasma of patients with T-tube drainage of bile were the lowest of the group. The significance of the hepato-biliary-enteric circulation of estrogens in relation to the slow urinary excretion of the radioactivity is discussed.

\section{ACKNOWLEDGMENTS}

We wish to thank Dr. John Paine, Professor of Surgery, University of Buffalo Medical School, for his interest in the study and for his cooperation in making available to us patients with $\mathrm{T}$-tube drainage. We wish to thank Mrs. Lucille Zablotny, Miss Maria Foldes and Mr. Lawrence Beecher for technical assistance.

\section{REFERENCES}

1. Smith, G. V., and Smith, O. W., Observations concerning the metabolism of estrogens in women. Am. J. Obst. \& Gynec., 1938, 36, 769.

2. Pearlman, W. H., and Pincus, G., The metabolism of estrone in men. J. Biol. Chem., 1943, 147, 379

3. Pincus, G., and Pearlman, W. H., Metabolism of estrone in men and non-pregnant women. Endocrinology, 1942, 31, 507.

4. Heard, R. D. H., and Hoffman, M. M., Steroids IV. The fate in man of injected $\alpha$-estradiol. J. Biol. Chem., 1941, 141, 329.

5. Zondek, B., and Black, R., Estrone clearance test in infectious hepatitis. J. Clin. Endocrinol., 1947, 7, 519.

6. Paschkis, K. E., and Rakoff, A. E., Some aspects of the physiology of estrogenic hormones. Rec. Prog. Hormone Research, 1950, 5, 115.

7. Gsell-Busse, M. A., Thelykinine in der Galle. Klin. Wchnschr., 1928, 7, 1606.

8. Dohrn, M., and Faure, W., Uber die Ausscheidung des weiblichen Sexual hormones. Klin. Wchnschr., 1928, 7, 943.

9. Cantarow, A., Rakoff, A. E., Paschkis, K. E., Hansen, L. P., and Walking, A. A., Excretion of estrogen in bile. Endocrinology, 1942, 31, 515.

10. Cantarow, A., Rakoff, A. E., Paschkis, K. E., Hansen, L. P., and Walking, A. A., Excretion of exogenous and endogenous estrogen in bile of dogs and humans. Proc. Soc. Exper. Biol. \& Med., 1943, 52, 256.

11. Pearlman, W. H., Paschkis, K. E., Rakoff, A. E., Cantarow, A., Walking, A. A., and Hansen, L. P., A note on the biliary excretion of endogenous estrogens. Endocrinology, 1945, 36, 284.

12. Pearlman, W. H., Rakoff, A. E., Cantarow, A., and Paschkis, K. E., The isolation of estrone from the bile of pregnant cows. J. Biol. Chem., 1947, 170, 173.

13. Pearlman, W. H., Rakoff, A. E., Paschkis, K. E., Cantarow, A., and Walking, A. A., The metabolic fate of estrone in bile-fistula dogs. J. Biol. Chem., 1948, 173, 175.

14. Pearlman, W. H., and Rakoff, A. E., A note on the estrogens in the bile of pregnant women. Endocrinology, 1949, 44, 199.

15. Twombly, G. H., and Schoenewaldt, E. F., The metabolism of radioactive dibromoestrone in man. Cancer, 1950, 3, 601. 
16. Albert, S., Heard, R. D. H., Leblond, C. P., and Saffran, J., Distribution and metabolism of iodo- $\alpha-$ estradiol labeled with radioactive iodine. J. Biol. Chem., 1949, 177, 247.

17. Beer, C. T., and Gallagher, T. F., Excretion of estrogen metabolites by humans. I. The fate of small doses of estrone and estradiol-17ק. J. Biol. Chem., $1955,214,335$.

18. Beer, C. T., and Gallagher, T. F., Excretion of estrogen metabolites by humans. II. The fate of large doses of estradiol-17 $\beta$ after intramuscular and oral administration. J. Biol. Chem., 1955. 214, 351.

19. Rakoff, A. E., Cantarow, A., Paschkis, K. E., Hansen, L. P., and Walking, A. A., Removal of exogenous estrogens from the circulation. Endocrinology, 1944, 34, 370.

20. Albrieux, A. S., The distribution of estrogens in the blood of pregnant and non-pregnant women. J. Clin. Endocrinol., 1941, 1, 893.

21. Albrieux, A. S., Estrogen content of the blood at four-hour intervals. Proc. Soc. Exper. Biol. \& Med., 1941, 47, 380.

22. Bischoff, F., and Katherman, R. E., Distribution of estradiol between serum and red cells. Am. J. Physiol., 1948, 152, 189.

23. Slaunwhite, W. R., Jr., and Sandberg, A. A., Studies on phenolic steroids in human subjects. I. The conversion of $16-C^{14}$-estrone to $\mathrm{C}^{16}$-16-ketoesterone. Arch. Biochem., 1956, 63, 478.

24. Rothchild, I., A simple method for the preparation of aqueous solutions of steroid hormones for intravenous administration. Endocrinology, 1952, 50, 583.

25. Sandberg, A. A., and Slaunwhite, W. R., Jr., Metabolism of 4-C $\mathrm{C}^{\mathbf{3}}$-testosterone in human subjects. I. Distribution in bile, blood, feces and urine. J. Clin. Invest., 1956, 35, 1331.

26. Fukushima, D. K., Bradlow, H. L., Dobriner, K., and Gallagher, T. F., The fate of testosterone infused intravenously in man. J. Biol. Chem., 1954, 206, 863.

27. Hellman, L., Bradlow, H. L., Adesman, J., Fukushima, D. K., Kulp, J. L., and Gallagher, T. F., The fate of hydrocortisone-4-C $\mathrm{C}^{16}$ in man. J. Clin. Invest., 1954, 33, 1106.

28. Peterson, R. E., Wyngaarden, J. B., Guerra, S. L., Brodie, B. B., and Bunim, J. J., The physiological disposition and metabolic fate of hydrocortisone in man. J. Clin. Invest., 1955, 34, 1779.

29. Migeon, C. J., Sandberg, A. A., Decker, H. A., Smith, D. F., Paul, A. C., and Samuels, L. T., Metabolism of 4-C'-cortisol in man: Body distribution and rates of conjugation. J. Clin. Endocrinol. \& Metab., 1956, 16, 1137.
30. Migeon, C. J., Sandberg, A. A., Paul, A. C., and Samuels, L. T., Metabolism of 4-C14-corticosterone in man. J. Clin. Endocrinol. \& Metab., 1956, 16, 1291.

31. Bradlow, H. L., Hellman, L., and Gallagher, T. F., Metabolism of 11-hydroxy- $\Delta^{4}$-androstene-3,17-dione4-C14. Federation Proc., 1956, 15, 223.

32. Pearlman, W. H., Pearlman, M. R. J., and Rakoff, A. E., Estrogen metabolism in human pregnancy ; a study with the aid of deuterium. J. Biol. Chem., 1954, 209, 803.

33. Levitz, M., Spitzer, J. R., and Twombly, G. H., The conversion of estradiol-17 $\beta-16-C^{14}$ to radioactive 16-ketoestradiol-17 $\beta$ in man. J. Biol. Chem., 1956, 222, 981.

34. Marrian, G. F., and Bauld, W. S., The isolation of 16epioestriol from the urine of pregnant women. Biochem. J., 1955, 59, 136.

35. Marrian, G. F., Watson, E. J. D., and Panattoni, M., The isolation of a ketonic dihydroxy Kober chromogen from the urine of pregnant women. Biochem. J., 1957, 65, 12.

36. Sandberg, A. A., and Slaunwhite, W. R., Jr., Unpublished observations.

37. Longwell, B. B., and McKee, F. S., The excretion of estrogens in the bile and urine after the administration of estrone. J. Biol. Chem., 1942, 142, 757.

38. Hellman, L., Bradlow, H. L., Frazell, E. L., and Gallagher, T. F., Tracer studies of the absorption and fate of steroid hormones in man. J. Clin. Invest., 1956, 35, 1033.

39. Rubin, B. L., Dorfman, R. I., and Miller, M., Androgen excretion in human bile. Endocrinology, 1952, $51,463$.

40. Stimmel, B. F., Simultaneous biliary and urinary exogenous estrogen excretion studies in man. Federation Proc., 1951, 10, 254.

41. Stimmel, B. F., Reduction of radioactive estrone to estradiol by human feces. Federation Proc., 1954, 13, 305.

42. Szego, C. M., The influence of the liver upon estrogen-protein binding in vitro. Endocrinology, 1953, 52, 669.

43. Riegel, I. L., and Mueller, G. C., Formation of a protein-bound metabolite of estradiol-16- $\mathrm{C}^{14}$ by rat liver homogenates. J. Biol. Chem., 1954, 210, 249.

44. Sandberg, A. A., and Slaunwhite, W. R., Jr., Biliary excretion and protein binding of radioactive steroids in human subjects: Their possible relationship. J. Clin. Endocrinol. \& Metab., 1956, 16, 923.

45. Gray, C. L., and Bischoff, F., Conversion of estrone to estradiol by mammalian red cells. Am. J. Physiol., 1955, 180, 279. 